This article is licensed under the Creative Commons Attribution-NonCommercial 4.0 International License (CC BY-NC) (http://www.karger.com/Services/OpenAccessLicense). Usage and distribution for commercial purposes requires written permission.

\title{
Interstitial Pneumonitis Secondary to Trastuzumab: A Case Report and Literature Review
}

\author{
Ricardo Costa $^{a}$ Rubens B. Costa-Filho ${ }^{a}$ Sarah M. Talamantes ${ }^{b}$ \\ Fernando Queiroga Jr ${ }^{c}$ Emmanuel C. Campello ${ }^{c}$ Henrique Cartaxo ${ }^{d}$ \\ Rubens B. Costa ${ }^{\mathrm{e}}$ \\ aDivision of Hematology/Oncology, Feinberg School of Medicine, Chicago, IL, USA; \\ ${ }^{b}$ Feinberg School of Medicine, Chicago, IL, USA; ${ }^{\mathrm{C} D i v i s i o n}$ of Pulmonary Medicine, Real \\ Hospital Portugues, Recife, Brazil; ${ }^{d}$ Department of Radiology, Real Hospital Portugues, \\ Recife, Brazil; ${ }^{e}$ Instituto de Diagnostico e Tratamento Oncologico, Recife, Brazil
}

\section{Keywords}

Breast cancer $\cdot$ Toxicity $\cdot$ Trastuzumab $\cdot$ Pneumonitis

\begin{abstract}
Interstitial lung disease is a rare complication of trastuzumab-based breast cancer treatment with few case reports published. Herein, we report the case of a 67-year-old female with early-stage HER2-postitive breast cancer who developed interstitial pneumonitis during cycle 5 of treatment with trastuzumab combined with carboplatin and docetaxel. After supportive care and treatment with prednisone, the patient showed rapid improvement of respiratory symptoms. Retreatment with trastuzumab as a single agent led to worsening of symptoms and required a second course of treatment with prednisone combined with cyclophosphamide, which was followed by improvement of symptoms. In conclusion, interstitial pneumonitis is a rare but life-threatening adverse event from trastuzumab breast cancer treatment.
\end{abstract}




\section{Case Reports in Oncology}

\section{Introduction}

Trastuzumab is a monoclonal antibody directed against HER2, which is overexpressed/ amplified in about $25 \%$ of breast cancers [1]. Taxanes are chemotherapeutic agents commonly used for the adjuvant treatment of HER2-positive breast tumors. The combination of taxanes with trastuzumab led to decreased recurrence rates in patients with high-risk earlystage HER2-positive breast cancer [2]. Furthermore, large randomized trials showed that adjuvant treatment with trastuzumab significantly improves overall survival and is a standard-of-care treatment option for HER2-positive breast cancer [2].

Drug-induced pneumonitis is a rare but well-documented adverse event (AE) of chemotherapy agents used in the adjuvant treatment of breast cancer (e.g., docetaxel and paclitaxel). Taxane-induced pneumonitis is described in a few case reports and case series with an estimated risk of $\sim 5 \%$ [3]. This is an often lethal toxicity despite treatment with glucocorticoids.

Of note, as targeted therapies gained unprecedented momentum for the treatment of HER2-positive breast cancer, their inherently distinct toxicity profile should be noted. For instance, treatment with trastuzumab has been consistently associated with an increased risk of congestive heart failure as observed in several large clinical trials [4]. There are rare accounts of interstitial pneumonitis associated with administration of trastuzumab for the treatment of breast cancer. Herein, we report a case of interstitial pneumonitis associated with trastuzumab treatment.

\section{Case Report}

A 67-year-old female presented with a diagnosis of nuclear grade 3, HER2-positive, estrogen receptor-positive, invasive ductal carcinoma of the left breast. Physical examination showed clinically positive left axilla. The patient underwent left-sided lumpectomy with axillary lymph node dissection. Pathological staging showed a single focus of invasive ductal carcinoma, measuring $1.5 \mathrm{~cm}$ in greatest dimension, 7 out of 9 positive lymph nodes for macrometastasis, and extracapsular invasion (pT1N2a). The patient underwent radiologic staging with computerized tomography (CT) with no signs of metastatic disease or lung infiltrates (cl 1A).

She also had a positive medical history for congestive heart failure after coronary artery bypass grafting 8 years prior to presentation of breast cancer. Transthoracic echocardiogram showed preserved ejection fraction prior to trastuzumab therapy. Six weeks after surgery, the patient was initiated on adjuvant treatment with carboplatin AUC 5, docetaxel 75 $\mathrm{mg} / \mathrm{m}^{2}$, and trastuzumab $8 \mathrm{mg} / \mathrm{kg}$ loading dose followed by $6 \mathrm{mg} / \mathrm{kg}$ on an every 21 days cycle (TCH). The patient received 5 full-dose cycles of TCH when she started to develop shortness of breath on exertion with associated dry cough on cycle 5, day 14, requiring hospitalization. There was no fever, chills, or any other clinical signs of infection. CT of the thorax was performed which showed ground glass opacities on both lungs suggestive of interstitial pneumonitis (Fig. 1b). Repeat transthoracic echocardiogram showed preserved systolic and diastolic cardiac function. To investigate infectious etiology, a bronchoscopy was performed; no significant pathological findings in the bronchial mucosae were observed. Bron- 


\section{Case Reports in Oncology}

Case Rep Oncol 2017;10:524-530

DOI: $10.1159 / 000477340$

(C) 2017 The Author(s). Published by S. Karger AG, Basel www.karger.com/cro

Costa et al.: Interstitial Pneumonitis Secondary to Trastuzumab: A Case Report and Literature Review

choalveolar lavage was collected, and a wide microbiological test (i.e., mycobacterial search and culture, fungus culture, and quantitative PCR for Pneumocystis jirovecii) did not show evidence of infectious disease. Pulmonary function tests, with spirometry, lung volumes by body plethysmography, and carbon monoxide diffusing capacity (DLCO) were performed, showing decreased values of forced vital capacity, total lung capacity, and a severe reduction in DLCO, which was compatible with restrictive ventilatory disorder and severe impairment in oxygen transfer rate (Table 1). These results, associated with altered tomographic images, supported the diagnosis of a severe interstitial lung disease likely secondary to drug-related toxicity. The patient was started on treatment with prednisone $40 \mathrm{mg}$ by mouth daily with clinical and radiological improvement (Fig. 1c).

After clinical improvement of shortness of breath, the patient was resumed on therapy with trastuzumab without docetaxel or carboplatin in combination with letrozole $2.5 \mathrm{mg}$ by mouth daily. The patient underwent 2 more cycles of trastuzumab every 3 weeks. Two weeks after the last infusion of trastuzumab, the patient developed worsening shortness of breath and was admitted to the hospital for supportive care. CT of the chest was performed after worsening of respiratory symptoms and after reexposure to trastuzumab, which showed worsening of ground glass infiltrates in both lungs (Fig. 1d). Pulmonary function tests were again performed and showed a decline in main pulmonary parameters related to a worsening of a previous restrictive ventilatory disorder, with an additional reduction in DLCo. The patient restarted daily oral prednisone $40 \mathrm{mg}$ combined with intravenous cyclophosphamide $\left(750 \mathrm{mg} / \mathrm{m}^{2}\right.$ of body surface area) with subsequent clinical improvement. The patient was discharged home 14 days after admission to the hospital on oxygen supplementation per nasal cannula, which was subsequently tapered down during the course of the next 4 weeks.

\section{Discussion}

Treatment-related lung damage is a known complication of cytotoxic chemotherapy [5]. Increased risk of iatrogenic pneumonitis has been associated more frequently with specific chemotherapy agents such as bleomycin (8-10\%) [6]. Trastuzumab was approved for the treatment of HER2-positive breast cancer in 1998 and has shown a favorable toxicity profile for the treatment of both localized as well as metastatic breast cancer with few cases of lung toxicity identified thus far.

A total of 1,672 women were treated with adjuvant trastuzumab in the NSABP B-31 and N9831 trials [7]. In the NSABP B-31 trial, 4 patients in the trastuzumab group had interstitial pneumonitis ( 1 of whom died), whereas in the N9831 trial, 5 patients in the trastuzumab group had grade 3 pneumonitis or pulmonary infiltrates ( 1 of whom died). Among 1,677 patients evaluable for toxicity in the HERA trial, no pneumonitis was reported [8]. Taken together, these results indicate that lung toxicities affect only $\sim 0.5 \%$ of patients receiving trastuzumab in the adjuvant setting and may represent a life-threatening $\mathrm{AE}$.

Indeed, case reports of trastuzumab-related interstitial pneumonitis are scarce, despite widespread administration of trastuzumab for the treatment of HER2-positive breast cancer (Table 2). Among the 7 cases of trastuzumab-related pneumonitis reported, all AEs led to hospitalization. One death was reported which occurred after a single infusion of trastuzu- 
mab in the adjuvant setting. Also, in most cases reported, patients were either under treatment with trastuzumab in combination with taxanes or had previously been exposed to taxanes prior to initiation of trastuzumab-induced pneumonitis. Our patient presented with severe pneumonitis (i.e., grade 3) after 5 cycles of adjuvant treatment with standard TCH. In parallel with previously described cases, this patient presented with severe AE leading to hospitalization and promptly responded to corticosteroid treatment. Nonetheless, our patient had worsening of respiratory symptoms and decline in forced vital capacity, total lung capacity, and DLCo after reexposure to trastuzumab, indicating that trastuzumab caused lung damage as a monotherapy. At the latter point in time, the patient required cyclophosphamide-based therapy in combination with oral corticosteroid with rapid clinical improvement.

In summary, notwithstanding the clinically meaningful benefit and the excellent tolerance of trastuzumab for the treatment of HER2-positive breast cancer, physicians should be aware of and check for rare and serious trastuzumab-related lung toxicities. Furthermore, pulmonary function tests may be considered as an additional tool for the diagnosis of druginduced pneumonitis.

\section{Statement of Ethics}

The authors have no ethical conflicts to disclose.

\section{Disclosure Statement}

The authors have no conflicts of interest to declare.

\section{References}

1 Slamon DJ, Clark GM, Wong SG, Levin WJ, Ullrich A, McGuire WL: Human breast cancer: correlation of relapse and survival with amplification of the HER-2/neu oncogene. Science 1987;235:177-182.

-2 Slamon D, Eiermann W, Robert N, Pienkowski T, Martin M, Press M, et al: Adjuvant trastuzumab in HER2-positive breast cancer. N Engl J Med 2011;365:1273-1283.

3 Chen YM, Shih JF, Perng RP, Tsai CM, Whang-Peng J: A randomized trial of different docetaxel schedules in non-small cell lung cancer patients who failed previous platinum-based chemotherapy. Chest 2006;129:1031-1038.

-4 Costa RB, Kurra G, Greenberg L, Geyer CE: Efficacy and cardiac safety of adjuvant trastuzumab-based chemotherapy regimens for HER2-positive early breast cancer. Ann Oncol 2010;21:2153-2160. Snyder LS, Hertz MI: Cytotoxic drug-induced lung injury. Semin Respir Infect 1988;3:217-228. Jules-Elysee K, White DA: Bleomycin-induced pulmonary toxicity. Clin Chest Med 1990;11:1-20. Romond EH, Perez EA, Bryant J, Suman VJ, Geyer CE Jr, Davidson NE, et al: Trastuzumab plus adjuvant chemotherapy for operable HER2-positive breast cancer. N Engl J Med 2005;353:1673-1684.

8 Piccart-Gebhart MJ, Procter M, Leyland-Jones B, Goldhirsch A, Untch M, Smith I, et al: Trastuzumab after adjuvant chemotherapy in HER2-positive breast cancer. N Engl J Med 2005;353:1659-1672.

-9 Lee HE, Jeong NJ, Lee Y, Seo YJ, Kim CD, Lee JH, et al: Radiation recall dermatitis and pneumonitis induced by trastuzumab (Herceptin(R)). Int J Dermatol 2014;53:e159-e160.

10 Abulkhair O, El Melouk W: Delayed paclitaxel-trastuzumab-induced interstitial pneumonitis in breast cancer. Case Rep Oncol 2011;4:186-191. 


\section{Case Reports in Oncology}

\begin{tabular}{l|l}
\hline Case Rep Oncol 2017;10:524-530 \\
\hline DOI: $10.1159 / 000477340$ & $\begin{array}{l}\text { C) 2017 The Author(s). Published by S. Karger AG, Basel } \\
\text { www.karger.com/cro }\end{array}$ \\
\hline
\end{tabular}

Costa et al.: Interstitial Pneumonitis Secondary to Trastuzumab: A Case Report and Literature Review

11 Kuip E, Muller E: Fatal pneumonitis after treatment with docetaxel and trastuzumab. Neth J Med 2009;67:237-239.

12 Bettini AC, Tondini C, Poletti P, Caremoli ER, Guerra U, Labianca R: A case of interstitial pneumonitis associated with Guillain-Barre syndrome during administration of adjuvant trastuzumab. Tumori 2008;94:737-741.

13 Vahid B, Mehrotra A: Trastuzumab (Herceptin)-associated lung injury. Respirology 2006;11:655-658.

14 Pepels MJ, Boomars KA, van Kimmenade R, Hupperets PS: Life-threatening interstitial lung disease associated with trastuzumab: case report. Breast Cancer Res Treat 2009;113:609-612.

15 Radzikowska E, Szczepulska E, Chabowski M, Bestry I: Organising pneumonia caused by transtuzumab (Herceptin) therapy for breast cancer. Eur Respir J 2003;21:552-555.
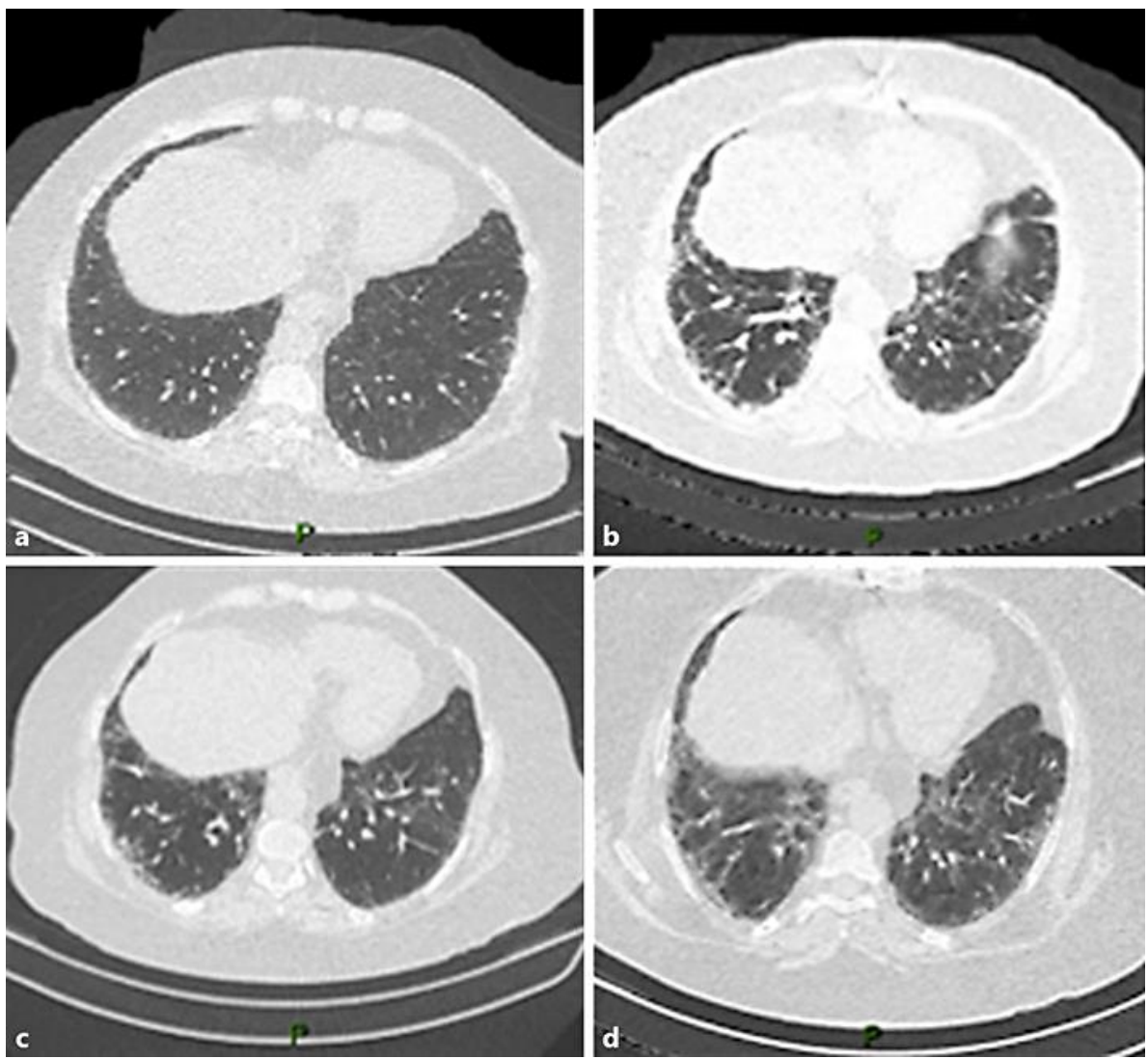

Fig. 1. Computerized tomography (CT) of the chest before, during, and after treatment. a Staging CT of the chest showing absence of lung disease. $\mathbf{b}$ CT of the chest performed after 5 cycles of adjuvant treatment with carboplatin, docetaxel, and trastuzumab. CT shows ground glass opacities on both lungs. c CT of the chest showing improvement of ground glass opacities after discontinuation of docetaxel, carboplatin, and trastuzumab. $\mathbf{d}$ CT of the chest showing worsening ground glass opacities on both lungs after trastuzumab reexposure. 


\section{Case Reports in Oncology}

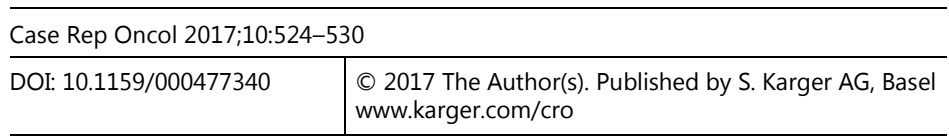
www.karger.com/cro

Costa et al.: Interstitial Pneumonitis Secondary to Trastuzumab: A Case Report and Literature Review

Table 1. Pulmonary function tests in July and October 2014, when the patient's respiratory symptoms worsened

\begin{tabular}{|c|c|c|}
\hline & July 2014 & October 2014 \\
\hline \multicolumn{3}{|l|}{ Spirometry } \\
\hline FVC, L & $1.61(67 \%)$ & $1.36(57 \%)$ \\
\hline $\mathrm{FEV}_{1}, \mathrm{~L}$ & $1.37(70 \%)$ & $1.18(60 \%)$ \\
\hline $\mathrm{FEV}_{1} / \mathrm{FVC}$ & $0.85(104 \%)$ & $0.87(106 \%)$ \\
\hline $\mathrm{FEF}_{25-75 \%} / \mathrm{FVC}$ & 112 (131\%) & $179(209 \%)$ \\
\hline $\mathrm{PEF}, \mathrm{L} \times \mathrm{s}^{-1}$ & $5.10(84 \%)$ & $4.29(71 \%)$ \\
\hline \multicolumn{3}{|l|}{ Lung volumes } \\
\hline TLC, L & $2.38(67 \%)$ & $2.08(58 \%)$ \\
\hline $\mathrm{RV}, \mathrm{L}$ & $0.88(76 \%)$ & $0.69(60 \%)$ \\
\hline TGV, L & $1.34(51 \%)$ & $1.19(45 \%)$ \\
\hline \multicolumn{3}{|l|}{ Diffusing capacity } \\
\hline DLCO, $\mathrm{mL} \times \mathrm{mm} \mathrm{Hg}^{-1} \times \mathrm{min}^{-1}$ & $5.58(28 \%)$ & $5.00(25 \%)$ \\
\hline $\mathrm{AV}, \mathrm{L}$ & $2.43(71 \%)$ & $2.13(62 \%)$ \\
\hline \multicolumn{3}{|c|}{ 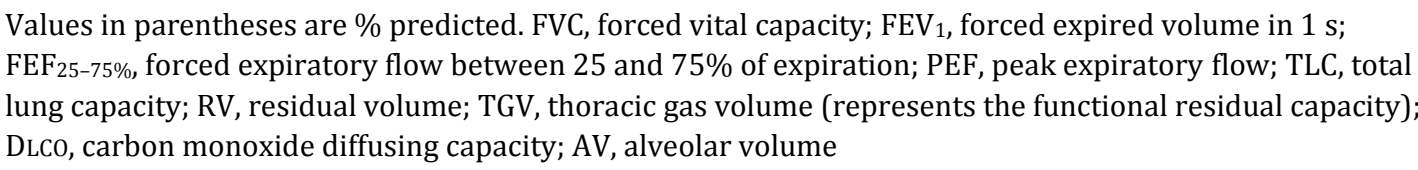 } \\
\hline
\end{tabular}




\section{Case Reports in Oncology}

Costa et al.: Interstitial Pneumonitis Secondary to Trastuzumab: A Case Report and Literature Review

Table 2. Case reports of trastuzumab-related pneumonitis

\begin{tabular}{|c|c|c|c|c|c|c|c|c|c|}
\hline $\begin{array}{l}\text { First author } \\
\text { [Ref.] }\end{array}$ & $\begin{array}{l}\text { Patient's age } \\
\text { at diagnosis, } \\
\text { years }\end{array}$ & $\begin{array}{l}\text { Breast } \\
\text { cancer } \\
\text { stage at } \\
\text { diagnosis }\end{array}$ & Comorbidities & $\begin{array}{l}\text { Treatment } \\
\text { prior to } \\
\text { initiation of } \mathrm{Tz}\end{array}$ & Treatment & $\begin{array}{l}\text { Time to } \\
\text { initiation of } \\
\text { respiratory } \\
\text { symptoms }\end{array}$ & $\begin{array}{l}\text { Highest } \\
\text { grade }^{1}\end{array}$ & $\begin{array}{l}\text { Pneumonitis } \\
\text { treatment }\end{array}$ & $\begin{array}{l}\text { Time to } \\
\text { resolution of } \\
\text { respiratory } \\
\text { symptoms }\end{array}$ \\
\hline Lee [9] & 55 & $\begin{array}{l}\text { axillary } \\
\text { positive }\end{array}$ & NR & $\begin{array}{l}\mathrm{S} \rightarrow \mathrm{XRT} 50.4 \text { Gy } \\
\text { in } 4 \text { weeks }\end{array}$ & $\begin{array}{l}\text { Tz every } \\
3 \text { weeks }\end{array}$ & $\begin{array}{l}\text { week } 32 \text { of } \\
\text { Tz therapy }\end{array}$ & NR & NR & NR \\
\hline $\begin{array}{l}\text { Abulkhair } \\
{[10]}\end{array}$ & 51 & $\begin{array}{l}\text { axillary } \\
\text { positive }\end{array}$ & none & none & $\begin{array}{l}\text { paclitaxel + } \\
\text { weekly Tz }\end{array}$ & $\begin{array}{l}\text { week } 10 \text { of } \\
\text { Tz therapy }\end{array}$ & 3 & $\begin{array}{l}\text { SC and } \\
\text { corticosteroid }\end{array}$ & NR \\
\hline Kuip [11] & 63 & LABC & NR & none & $\begin{array}{l}\text { docetaxel + } \\
\text { Tz every } 3 \\
\text { weeks }\end{array}$ & $\begin{array}{l}\text { week } 1 \text { of } \\
\text { Tz therapy }\end{array}$ & 5 & $\begin{array}{l}\text { SC and } \\
\text { corticosteroid }\end{array}$ & NA \\
\hline $\begin{array}{l}\text { Bettini } \\
{[12]}\end{array}$ & 65 & $\begin{array}{l}\text { axillary } \\
\text { positive }\end{array}$ & $\begin{array}{l}\text { sciatic } \\
\text { neuralgia }\end{array}$ & $\begin{array}{l}\mathrm{S} \rightarrow \text { epirubicin }+ \\
\text { cyclophosphamide } \\
\times 4 \rightarrow \text { paclitaxel } \times 4\end{array}$ & $\begin{array}{l}\text { Tz every } \\
3 \text { weeks }+ \\
\text { XRT }\end{array}$ & week 5 & 3 & $\begin{array}{l}\text { SC and } \\
\text { corticosteroid }\end{array}$ & NR \\
\hline $\begin{array}{l}\text { Vahid } \\
{[13]}\end{array}$ & 72 & stage IV & $\begin{array}{l}\text { lung and } \\
\text { pleural } \\
\text { metastases }\end{array}$ & $\mathrm{S} \rightarrow$ tamoxifen & $\begin{array}{l}\text { Tz every } \\
2 \text { weeks }\end{array}$ & week 9 & 4 & $\begin{array}{l}\text { SC and } \\
\text { corticosteroid }\end{array}$ & \\
\hline $\begin{array}{l}\text { Pepels } \\
{[14]}\end{array}$ & 56 & stage IV & $\begin{array}{l}\text { abdominal } \\
\text { lymphadenopathy }\end{array}$ & $\mathrm{FAC} \times 6 \rightarrow \mathrm{S}$ & $\begin{array}{l}\text { docetaxel + } \\
\text { Tz every } 3 \\
\text { weeks }\end{array}$ & week 20 & 3 & $\begin{array}{l}\text { SC and } \\
\text { corticosteroid }\end{array}$ & NR \\
\hline $\begin{array}{l}\text { Radzikowska } \\
\text { [15] }\end{array}$ & 49 & LABC & epilepsy & $\mathrm{S} \rightarrow \mathrm{AC} \times 4 \rightarrow \mathrm{XRT}$ & $\begin{array}{l}\text { docetaxel } \\
\text { Tz every } \\
\text { week }\end{array}$ & week 6 & 3 & SC & 3 months \\
\hline
\end{tabular}

AC, doxorubicin, cyclophosphamide; FAC, 5-FU, doxorubicin, cyclophosphamide; NR, not reported; NA, not applicable; LABC, locally advanced breast cancer; S, surgery; SC, standard of care; Tz, trastuzumab; XRT, radiation therapy. ${ }^{1}$ Estimated based on National Cancer Institute Common Terminology Criteria Adverse Events (NCI CTCAE) v4.0. 